\title{
Ibrutinib-associated hematoma and ecchymosis in a patient with basal cell carcinoma who underwent Mohs micrographic surgery
}

\author{
Mohs mikrografik cerrahisi uygulanan bazal hücreli karsinomlu bir hastada ibrutinib
} ile ilișkili hematom ve ekimoz

\section{Sema Koç Yıldırım, ๑ Gonca Elçin*, ๑ Serdar Özer**, ๑ Özay Gököz***}

Afyonkarahisar State Hospital, Clinic of Dermatology, Afyonkarahisar, Turkey *Hacettepe University Faculty of Medicine, Department of Dermatology and Venereology; **Department of Otorhinolaryngology;

***Department of Pathology, Ankara, Turkey

\begin{abstract}
Basal cell carcinoma (BCC) is the most common skin cancer. The gold standard therapy is surgery in the treatment of BCC. The recomended surgical method is Mohs micrographic surgery, as it provides the highest cure rates in high-risk BCC in terms of recurrence. It is well known that certain drugs such as aspirin, warfarin and clopidogrel cause bleeding complications during dermatologic surgery. In contrast, it is not well known to have bleeding side effects similar to these drugs. Herein, we present ibrutinib-associated hematoma and ecchymosis in a patient with BCC who underwent Mohs micrographic surgery.

Keywords: Basal cell carcinoma, ibrutinib, hematoma, echymosis
\end{abstract}

\section{Öz}

Bazal hücreli karsinom (BCC) en sık görülen deri kanseridir. BCC tedavisinde, altın standart yöntem cerrahidir. Nüks açısından yüksek riskli BCC'de en yüksek kür oranlarını sağladığı için önerilen cerrahi yöntem Mohs mikrografik cerrahisidir. Aspirin, warfarin, klopidogrel gibi bazı ilaçların dermatolojik cerrahi sırasında kanama komplikasyonlarına neden olduğu çok iyi bilinmektedir. Buna karşılık ibrutinibinin de bu ilaçlara benzer kanama yan etkilerine sahip olduğu iyi bilinmemektedir. Burada Mohs mikrografik cerrahisi uygulanan BCC'li bir hastada ibrutinib nedeniyle gelişen hematom ve ekimoz sunulmuştur.

Anahtar Kelimeler: Bazal hücreli karsinom, ibrutinib, hematom, ekimoz

\section{Introduction}

Basal cell carcinoma $(B C C)$ is the most common skin cancer ${ }^{1}$. The gold standard therapy for BCC is surgery. Mohs micrographic surgery is the treatment of choice for those BCCs with high risk for recurrence because Mohs micrographic surgery provides the highest cure rates ${ }^{2}$. Ibrutinib is an agent that irreversibly inhibits "Bruton's kinase" which is an essential tyrosine kinase for B lymphocyte signalization. Ibrutinib is used for the treatment of chronic lymphocytic leukemia (CLL) and other B cell lymphomas ${ }^{3}$. Traditional oral anticoagulants and antiplatelet drugs including aspirin, warfarin and clopidogrel are very well-known drugs that cause bleeding complications during dermatologic surgery and are routinely checked before surgery in daily practice ${ }^{4}$. However, it is not well known that ibrutinib has similar bleeding side effects.

\section{Case Report}

A 68-year-old female patient was admitted to our clinic with the complaint of a hemorrhagic ulceration on her upper cutaneous lip which appeared 4-months ago. She had a

Address for Correspondence/Yazışma Adresi: Sema Koç Yıldırım MD, Afyonkarahisar State Hospital, Clinic of Dermatology, Afyonkarahisar, Turkey Phone: +90 5367371594 E-mail: semakocyildirim@gmail.com Received/Geliş Tarihi: 16.04.2019 Accepted/Kabul Tarihi: 14.01.2020 ORCID: orcid.org/0000-0002-0633-1770 
diagnosis of CLL for 3 years and was using $420 \mathrm{mg} /$ day ibrutinib for her CLL. Dermatologic examination revealed a black crusted ulcerated plaque of $1.2 \times 1.1 \mathrm{~cm}$ diameter with elevated shiny borders on the right side of the upper cutaneous lip (Figure 1). The pathology of a $4 \mathrm{~mm}$ punch biopsy specimen was reported as BCC with micronodular and focal infiltrative subtype.

This BCC was accepted as high-risk due to its perioral anatomical localization and its aggressive histopathological features. Thus, the patient was offered Mohs micrographic surgery and she agreed. Preoperative platelet counts were in normal values and ibrutinib treatment was not discontinued before surgery. Mohs micrographic surgery was applied as described in the literature ${ }^{5}$. Clear surgical margins were reached after one stage of Mohs micrographic surgery. The defect was repaired with a pedicled island flap from the adjacent cheek without

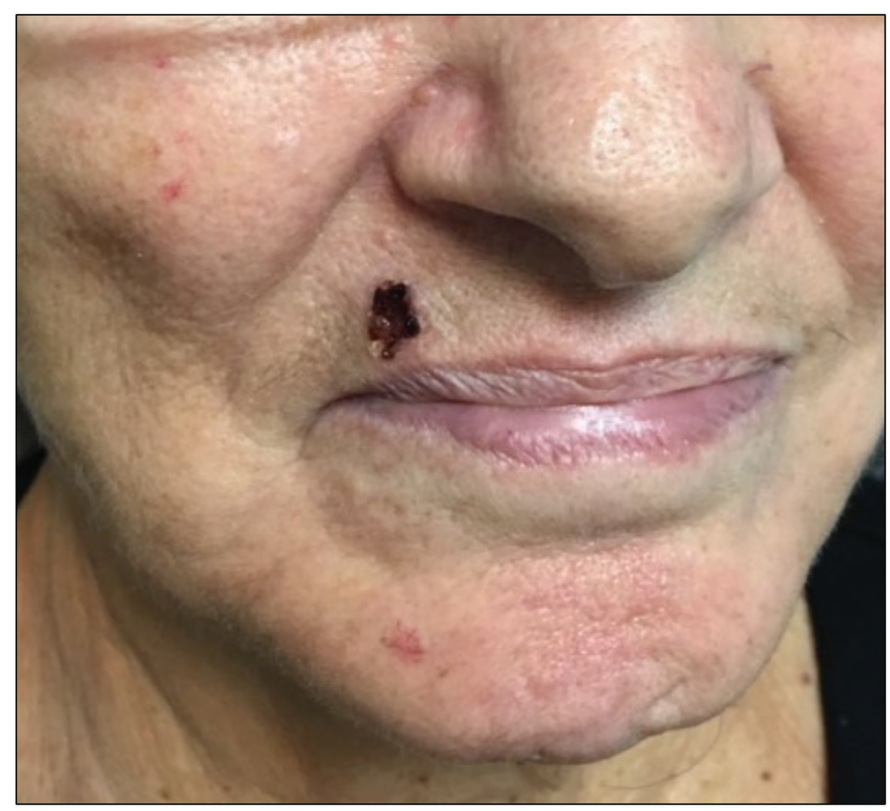

Figure 1. A pink papule about $1.2 \times 1.1 \mathrm{~cm}$ diameter with elevated borders on the right side of upper lip

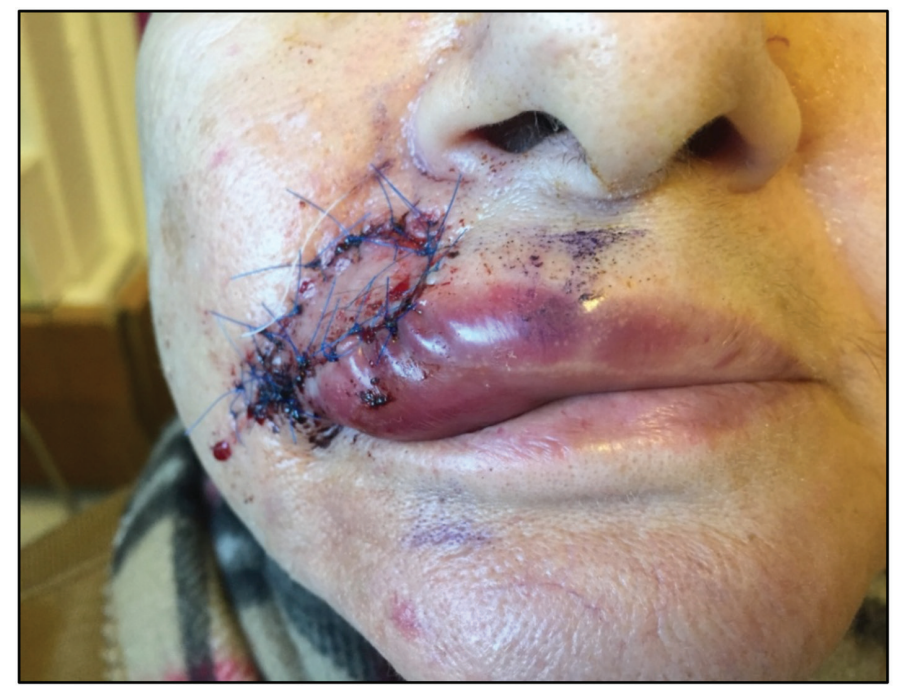

Figure 2. Widespread ecchymosis with extensive edema on the flap at postoperative $24^{\text {th }}$ hour any intraoperative complication. Despite proper intraoperative bleeding control and multiple subcutaneous suturing against dead space during the repair, extensive swelling on the right upper mucosal lip and right cheek was noticed at the postoperative $24^{\text {th }}$ hour control (Figure 2). On postoperative $7^{\text {th }}$ day, the swelling on the right side of the mucosal lip subsided while ecchymosis has widened to the right side of the chin and the neck (Figure 3). Ecchymosis spontaneously regressed almost totally on the $10^{\text {th }}$ day. The follow-up visit on the postoperative $90^{\text {th }}$ day revealed a good cosmetic result (Figure 4).

Informed consent was obtained from our patient.

\section{Discussion}

It is well documented that the complication rate of dermatologic surgery is very low $w^{6,7}$. Although there are no life-threatening bleeding events associated with cutaneous surgery reported in the literature, it was shown that patients taking both warfarin and clopidogrel have a higher

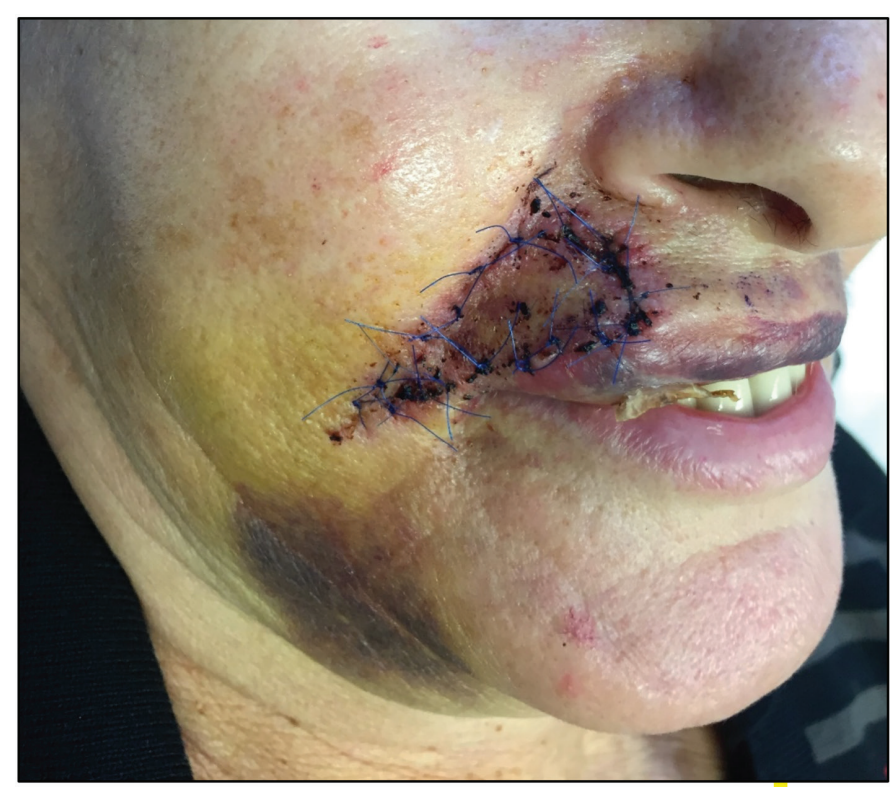

Figure 3. Extending ecchymosis to the chin and the neck on postoperative $7^{\text {th }}$ day

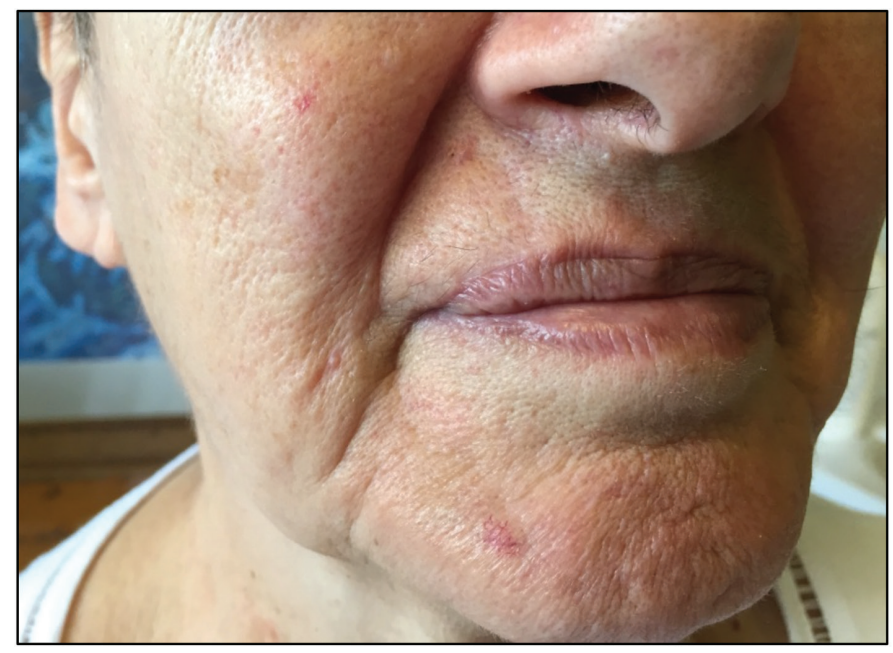

Figure 4. Good cosmetic result on postoperative $90^{\text {th }}$ day 
risk of bleeding. Other factors that increase the risk of hemorrhage are complex repairs that utilizes flaps, grafts or partial closures ${ }^{7}$.

Ibrutinib therapy was associated with an increased risk of bleeding in previous trials ${ }^{8}$. When compared with other standard chemotherapeutic drugs the increased risk of bleeding with ibrutinib was significantly higher$^{9}$. Although ibrutinib is well-tolerated, major bleeding events including subdural hematomas, hematuria and gastrointestinal bleeding were reported in up to $5 \%$ to $6 \%$ of patients ${ }^{10}$. Subcutaneous and mucosal bleeding including contusions, epistaxis, petechial bleeding and ecchymosis are the most common bleeding events associated with ibrutinib9. Although the situation about the preoperative discontinuation of ibrutinib treatment is not clear, it is suggested to consider withholding ibrutinib for at least 3 to 7 days pre and postsurgery depending upon the type of surgery and the risk of bleeding ${ }^{8}$. Recently, Parra et al. ${ }^{11}$ reported 2 patients who had ecchymosis on ibrutinib treatment after Mohs micrographic surgery for their squamous cell carcinomas located on their foreheads. Although ibrutinib was withheld for 3 days before Mohs micrographic surgery, extensive bilateral periorbital ecchymosis and hematoma at the site of the flap developed on postoperative $3^{\text {rd }}$ day in the first patient. In the second patient ibrutinib treatment was not discontinued, and ecchymosis down to the chin has developed. Similarly to our case, no immediate bleeding complications were encountered intra-operatively and spontaneous resolution occurred in the follow up period in both patients ${ }^{11}$.

Dermatologists are aware of questioning drugs that are likely to cause bleeding complications before cutaneous surgery. Aspirin, warfarin, clopidogrel, and even some herbals like ginseng, gingko, garlic and ginger are almost always questioned before dermatologic surgery and the patients are informed how to proceed. It should be kept in mind that bleeding complications are not rare in patients who are taking ibrutinib.

With the awareness of the potential bleeding side effects of ibrutinib, we believe that it is wise for dermatologic surgeons to include ibrutinib in the checklist of drugs that may cause bleeding complications during cutaneous surgery, and act accordingly.

\section{Ethics}

Informed Consent: Informed consent was obtained from our patient. Peer-review: Externally and internally peer-reviewed.

\section{Authorship Contributions}

Concept: S.K.Y., G.E., S.Ö., Ö.G., Design: S.K.Y., G.E, Data Collection or Processing: S.K.Y., G.E., S.Ö., Ö.G., Analysis or Interpretation: S.K.Y., G.E., S.Ö., Ö.G., Literature Search: S.K.Y, Writing: S.K.Y., Ö.G.

Conflict of Interest: No conflict of interest was declared by the authors.

Financial Disclosure: The authors declared that this study received no financial support.

\section{References}

1. Lang BM, Balermpas P, Bauer A, et al: S2k Guidelines for cutaneous basal cell carcinoma-part 1: Epidemiology, Genetics and Diagnosis. J Dtsch Dermatol Ges 2019;17:94-103.

2. Rowe DE, Carroll RJ, Day Jr CL: Long-term recurrence rates in previously untreated (primary) basal cell carcinoma: implications for patient follow-up. J Dermatol Surg Oncol 1989;15:315-28.

3. Lipsky AH, Farooqui MZH, Tian X, et al: Incidence and risk factors of bleeding related adverse events in patients with chronic lymphocytic leukemia treated with ibrutinib. Haematologica 2015;100:1571-8.

4. Lewis KG, Dufresne Jr RG: A meta-analysis of complications attributed to anticoagulation among patients following cutaneous surgery. Dermatol Surg 2008;34:160-4

5. Elçin G: How to perform Mohs micrographic surgery? Turkderm 2015;49:238 45.

6. Shimizu I, Jellinek NJ, Dufresne RG, Li T, Devarajan K, Perlis C: Multiple antithrombotic agents increase the risk of postoperative hemorrhage in dermatologic surgery. J Am Acad Dermatol 2008;58:810-6.

7. Bordeaux JS, Martires KJ, Goldberg D, Pattee SF, Fu P, Maloney ME: Prospective evaluation of dermatologic surgery complications including patients on multiple antiplatelet and anticoagulant medications. J Am Acad Dermatol 2011;65:576-83.

8. Caron F, Leong DP, Hillis C, Fraser G, Siegal D: Current understanding of bleeding with ibrutinib use: a systematic review and meta-analysis. Blood Adv 2017;1:772-8.

9. Shatzel JJ, Olson SR, Tao DL, McCarty OJT, Danilov AV, DeLoughery TG: Ibrutinib-associated bleeding: pathogenesis, management and risk reduction strategies. J Thromb Haemost 2017;15:835-47.

10. Byrd JC, Furman RR, Coutre SE, et al: Targeting BTK with ibrutinib in relapsed chronic lymphocytic leukemia. N Engl J Med 2013;369:32-42.

11. Parra CE, Newsom E, Lee EH, Allan JN, Minkis K: Association of Ibrutinib Treatment With Bleeding Complications in Cutaneous Surgery. JAMA Dermatol 2017;153:1069-70. 